\title{
PENGARUH KEMITRAAN TERHADAP PRODUKSI DAN PENDAPATAN USAHATANI SAYURAN DI KABUPATEN BOGOR
}

\author{
Susanti ${ }^{1}$, Nunung Kusnadii ${ }^{2}$ dan Dwi Rachmina ${ }^{3)}$ \\ ${ }^{1,2,3)}$ Departemen Agribisnis, Fakultas Ekonomi dan Manajemen,Institut Pertanian Bogor \\ ${ }^{1)}$ santiagb46@gmail.com
}

\begin{abstract}
The partnership between Gapoktan Rukun Tani and vegetable farmers in Bogor was designed to facilitate farmers in overcoming the limitations of production inputs, capital, and market certainty. This study compares a one year production and income of vegetables farmers who participate in the partnership to the non participated vegetables farmers in Bogor. Income analysis and $R / C$ ratio analysis show that the partnership has no influence in increasing the farm production and income. In term of average production, income and $R / C$ ratio, the partnership farmer was lower than that of non partnership farmer $(0,96 \%, 0,97 \%$, and 1,03 lower consecutively). However, the partnership farming increases the bargaining power of farmers by getting higher price and market certainty. Another advantage of paticipating in the partnership is higher access to both capital credit and production input.
\end{abstract}

Keyword(s): partnership, gapoktan, income analysis, analysis of $R / C$ ratio.

\begin{abstract}
ABSTRAK
Kemitraan yang diintroduksi oleh Gapoktan Rukun Tani kepada para petani sayuran dirancang untuk memudahkan petani dalam mengatasi keterbatasan input produksi, modal, dan kepastian pasar. Penelitian ini membandingkan hasil produksi dan pendapatan usahatani sayuran petani mitra dan petani non mitra selama satu tahun di Kabupaten Bogor. Dengan menggunakan analisis pendapatan dan $\mathrm{R} / \mathrm{C}$ rasio, diketahui bahwa kemitraan belum mampu meningkatkan produksi dan pendapatan usahatani. Hasil produksi rata-rata sayuran petani mitra lebih rendah $0,96 \%$ dibandingkan petani non mitra. Pendapatan usahatani terhadap biaya tunai dan biaya total yang diperoleh petani mitra lebih kecil $0,97 \%$ dibandingkan petani non mitra. Sedangkan nilai $\mathrm{R} / \mathrm{C}$ atas biaya total usahatani petani mitra sebesar 9,95, lebih kecil dibandingkan petani non mitra yang memperoleh nilai $\mathrm{R} / \mathrm{C}$ atas biaya total usahatani sebesar 10,98. Namun demikian, kemitraan mampu meningkatkan posisi tawar petani melalui perolehan harga yang lebih tinggi dan kepastian pasar. Kemitraan juga memberi manfaat kepada petani berupa akses terhadap pinjaman modal dan kemudahan memperoleh input produksi.
\end{abstract}

Kata Kunci: kemitraan, gapoktan, pendapatan usahatani, $\mathrm{R} / \mathrm{C}$ rasio.

\section{PENDAHULUAN}

Hortikultura merupakan produk pertanian yang memiliki karakteristik spesifik yaitu kadar air tinggi, bulky, voluminous atau meruah, dan mudah rusak (perishable). Hortikultura juga bersifat seasonable yaitu jumlahnya melimpah pada musim tertentu tetapi menjadi sangat langka pada musim yang lain. Sifat musiman hortikultura ini menyebabkan jumlahnya tidak stabil sehingga berpengaruh pada harganya 
yang sering berubah. Salah satu komoditi hortikultura yang memenuhi ciri-ciri diatas adalah sayuran.

Produksi sayuran semakin meningkat setiap tahunnya. Badan Pusat Statistik (2012) mencatat adanya trend peningkatan jumlah produksi beberapa jenis sayuran. Sejak tahun 2002-2011 diketahui bahwa laju peningkatan produksi terung sebesar 7,44 persen, buncis 4,43 persen, cabai sebesar 11,22 persen, kacang panjang sebesar 5,13 persen. Peningkatan laju produksi sayuran perlu dipertahankan dan didukung melalui upaya pengembangan usahatani sayuran yang mengarah pada peningkatan pendapatan atau keuntungan usahatani dan kesejahteraan petani sayuran. Di samping peningkatan jumlah produksi, peningkatan pendapatan usahatani dapat dicapai melalui penerimaan harga output yang lebih tinggi, kepastian pasar, terjaminnya keberlangsungan kegiatan usahatani, dan penggunaan input-input produksi yang lebih efisien. Kegiatan usahatani secara individu sulit mencapai kondisi tersebut. Namun, jika kegiatan usahatani dilakukan secara kolektif dengan hubungan kontrak pertanian memungkinkan petani untuk mencapai kondisi tersebut.

Hubungan kontrak atau kemitraan pertanian telah banyak dilakukan di berbagai negara dan secara nyata mampu meningkatkan kesejahteraan petani melalui peningkatan produksi (Burch dan Rickson (1990) dan Bolwig et al. (2009)) maupun melalui akses pasar dan harga yang lebih baik (Key N dan David (1999); Barham dan Clarence (2009); Hellin et al. (2009); dan Tita et al. (2011)) sehingga berpengaruh pada peningkatan pendapatan usahatani (Sukhpalsingh (2002) dan Bolwig et al. (2009).

Menurut Hafsah (1999), kemitraan agribisnis merupakan strategi bisnis yang dapat dilakukan oleh dua pihak atau lebih dalam jangka waktu tertentu, untuk menarik keuntungan bersama dengan prinsip saling membutuhkan, menguntungkan, saling memperkuat dengan memperhatikan tanggung jawab moral dan etika bisnis. Bentuk kemitraan seperti ini pada umumnya berupa sebuah koordinasi vertikal yang sering diikuti dengan hubungan kontrak atau adanya kesepakatan. Pada umumnya terdapat empat bentuk koordinasi vertikal (Berkama dan Drabenstott 1995 dan Rehber 1998) yaitu market coordination, contract farming, vertical integration, dan farmer cooperative. Diantara keempat bentuk koordinasi, farmer cooperative merupakan bentuk yang saat ini sbanyak dikembangkan baik dalam bentuk kelompok tani, Gapoktan, atau koperasi pertanian. Sebuah farmer cooperative dapat diikuti, dimiliki, dan dikendalikan oleh produsen pertanian (petani) untuk saling melengkapi kepentingan anggota baik sebagai produsen maupun sebagai pelanggan (Rehber 1984).

Bentuk koordinasi vertikal yang diungkapkan oleh Berkama dan Drabenstott (1995) serta Rehber (1998) umumnya berbentuk hubungan kontrak atau kemitraan yang berarti ada kesepakatan diantara dua pihak. Sukhpalsingh (2002) menyatakan bahwa kontrak pertanian telah menyebabkan pendapatan petani lebih tinggi dan 
mampu menyerap banyak tenaga kerja. Kemitraan memungkinkan bagi petani untuk menggunakan varietas tanaman baru (Burch dan Rickson 1990). Kemitraan juga menjadi sumber motivasi dibalik pengambilan keputusan petani skala kecil untuk meninggalkan pertanian tradisional dan berorientasi pada pasar yang lebih luas (Masakure dan Henson 2005).

Bolwig et al. (2009) mengungkapkan bahwa pertanian kontrak memungkinkan berbagai faktor produksi dikontrol dan berpengaruh pada pendapatan yang semakin positif. Petani yang ikut berpartisipasi dalam pertanian kontrak memperoleh peningkatan pendapatan bersih rata-rata $75 \%$ atau setara dengan $12,5 \%$ dari total pendapatan rumah tangga. Peningkatan pendapatan ini terkait dengan peluang petani untuk mengakses premi harga yang telah dijamin oleh kemitraan. Pertanian kontrak juga memungkinkan petani menerapkan teknik budidaya yang lebih baik dan menghasilkan tambahan pendapatan. Hal ini dapat dijelaskan oleh hubungan positif antara praktek-praktek teknik budidaya dan hasil produksi yang dicapai per pohon oleh petani peserta mitra.

Penelitian ini bertujuan untuk mengetahui pengaruh kemitraan terhadap hasil produksi dan pendapatan usahatani sayuran. Kemitraan yang dimaksud adalah hubungan pertanian kontrak antara Gapoktan Rukun Tani dengan petani sayuran di Kabupaten Bogor selama tahun 2012. Pengaruh kemitraan diketahui dengan membandingkan hasil produksi dan pendapatan usahatani petani mitra dengan petani non mitra di lokasi penelitian. Gapoktan Rukun tani sebagai salah bentuk farmer cooperative diduga mampu meningkatkan hasil produksi dan pendapatan usahatani sayuran melalui kemitraan atau hubungan kontrak yang dijalankan bersama petani sayuran.

\section{METODOLOGI}

Penelitian dilakukan pada bulan November-Desember 2013. Lokasi penelitian dipilih Kabupaten Bogor dengan pertimbangan: (a) terdapat daerah sentra produksi sayuran, dan (b) adanya pola kemitraan usaha antara petani sayuran dengan Gapoktan. Dari kriteria tersebut, terpilih Kecamatan Ciawi sebagai kecamatan contoh dan Desa Citapen sebagai desa contoh karena dilokasi tersebut terdapat Gapoktan Rukun Tani yang menjalankan kemitraan dengan petani sayuran. Selain terdapat petani sayuran yang bermitra dengan Gapoktan, di Desa Citapen juga terdapat petani sayuran lain yang menjalankan usahatani secara independen atau tidak bermitra sehingga sesuai dengan tujuan penelitian.

Jumlah responden dalam penelitian ini mencapai 34 responden, terdiri dari 20 responden petani mitra dan 14 responden petani non mitra yang dipilih secara acak melalui teknik simple random sampling. Data dikumpulkan dengan melakukan survei dan wawancara kepada petani contoh dengan bantuan kuesioner terstruktur. Data yang dikumpulkan mencakup karakteristik petani, luas tanam sayuran, input-output usahatani sayuran, harga input dan output usahatani, serta kelembagaan Gapoktan (Gabungan Kelompok Tani). Sedangkan data tam- 
bahan digunakan data sekunder meliputi gambaran umum lokasi penelitian, profil Gapoktan Rukun Tani, data produksi sayuran dari Badan Pusat Statistik, dan literatur pendukung lainnya yang relevan dengan topik penelitian baik dari jurnal maupun hasil-hasil penelitian sebelumnya yang sesuai.

Dalam kemitraan yang dijalankan, Gapoktan Rukun Tani bertindak sebagai penyedia input produksi, tenaga kerja, pemberi pinjaman modal usahatani, penjamin pasar bagi sayuran yang dihasilkan petani, serta memberikan fasilitas lain seperti bimbingan teknis dan sekolah lapang. Sementara petani berkewajiban menjual sayuran hasil panen ke Gapoktan. Kemitraan yang dijalankan dikuatkan oleh sebuah kontrak kesepakatan yang bersifat mengikat baik untuk petani maupun Gapoktan.

Usahatani sayuran yang dianalisis yaitu usahatani yang dijalankan satu tahun selama tahun 2012. Analisis kualitatif dan kuantitatif dilakukan berdasarkan data yang diperoleh. Analisis kualitatif digunakan untuk mengetahui gambaran karakteristik usahatani sayuran di lokasi penelitian. Analisis kuantitatif pada penelitiam dilakukan untuk menghitung pendapatan usahatani melalui analisis pendapatan usahatani. Setelah itu menganalisis faktor-faktor yang mempengaruhi minat petani sayuran untuk bermitra dan tidak bermitra dengan Gapoktan.

\section{Analisis Pendapatan Usahatani}

Menurut Soekartawi (1986), analisis pendapatan usahatani bertujuan untuk mengetahui besarnya keuntungan yang diperoleh dari kegiatan usahatani yang dilakukan oleh petani. Untuk menghitung pendapatan usahatani dapat digunakan rumus:

$$
\begin{aligned}
& \text { Pendapatan }(\pi)=\mathrm{TR}-\mathrm{TC} \\
& \text { Pendapatan }(\pi)=(\mathrm{P} \times \mathrm{Q})-(\text { Biaya Tunai } \\
& \quad+\text { Biaya Diperhitungkan }) \\
& \text { Dimana: } \\
& \text { TR : Total Penerimaan } \\
& \text { TC : Biaya Tunai + Biaya yang Diperhitungkan }
\end{aligned}
$$

Pendapatan dikatakan positif atau mengalami keuntungan apabila nilai pendapatan $(\pi)$ bernilai positif yang berarti total penerimaan yang diterima petani lebih besar dibandingkan total biaya yang dikeluarkan petani. Sebaliknya jika nilai pendapatan $(\pi)$ bernilai negatif, maka dapat dikatakan petani mengalami kerugian yang berarti total biaya yang dikeluarkan lebih besar dibandingkan total penerimaan yang diperoleh petani.

Pada penelitian ini komponen biaya atau pengeluaran usahatani meliputi biaya pengadaan faktor-faktor produksi yang terdiri dari lahan, pupuk kandang, pupuk kimia (Urea, TSP, KCL, NPK, dan lainnya), benih sayuran (cabai, buncis, caisin, kacang panjang, kapri, terung, tomat, jagung sayur, kacang damame, dan ketimun), tenaga kerja (tenaga kerja dalam keluarga dan luar keluarga), obatobatan (obat padat dan obat cair), penyusutan peralatan, dan biaya pasca panen. Sementara komponen penerimaan berasal dari satu faktor tunggal yaitu penjualan sayuran hasil panen petani. Pendapatan diperoleh dengan mengurangkan total penerimaan yang 
diperoleh petani dengan total biaya yang dikeluarkan petani.

\section{Analisis Rasio Penerimaan dengan Biaya yang Dikeluarkan (Analisis R/C Rasio)}

Analisis $\mathrm{R} / \mathrm{C}$ rasio bertujuan untuk menguji sejauh mana hasil yang diperoleh dari kegiatan usahatani menguntungkan atau sebaliknya. Analisis R/C membandingkan antara penerimaan yang diterima petani dengan biaya yang dikeluarkan pada satu periode tertentu. Perhitungan $\mathrm{R} / \mathrm{C}$ dibedakan menjadi dua yaitu perhitungan untuk $\mathrm{R} / \mathrm{C}$ atas biaya tunai dan $\mathrm{R} / \mathrm{C}$ atas biaya total. $\mathrm{R} / \mathrm{C}$ atas biaya tunai dihitung dengan membandingkan total penerimaan dengan biaya tunai. Sedangkan $\mathrm{R} / \mathrm{C}$ atas biaya total didapatkan dengan membandingkan total penerimaan dengan biaya total yang dikeluarkan. Dimana biaya total merupakan penjumlahan dari biaya tunai dan biaya diperhitungkan. Secara lebih singkat rumus untuk mendapatkan nilai $\mathrm{R} / \mathrm{C}$ rasio adalah sebagai berikut.

$\mathrm{R} / \mathrm{C}$ atas biaya tunai $=$ Total Penerimaan $(\mathrm{TR}=\mathrm{P} \times \mathrm{Q}) /$ Biaya Tunai

$\mathrm{R} / \mathrm{C}$ atas biaya total $=$ Total Penerimaan $(\mathrm{TR}=\mathrm{P} \times \mathrm{Q}) /$ Biaya Tunai + Biaya Diperhitungkan (TC)

Dalam kegiatan usahatani, petani harus mendapatkan rasio (imbangan) antara total penerimaan dan total biaya yang dikeluarkan harus lebih besar dari satu $(\mathrm{R} / \mathrm{C}>1)$. Jika nilai $\mathrm{R} / \mathrm{C}$ kurang dari satu petani akan mengalami kerugian karena berarti biaya yang dikeluarkan oleh petani lebih besar daripada total penerimaan yang diterima petani. Nilai $\mathrm{R} / \mathrm{C}$ rasio juga digunakan untuk mengukur tingkat keuntungan petani yaitu dengan mengukur besarnya rupiah pengembalian dari setiap Rp. 1 yang dikeluarkan petani.

\section{HASIL DAN PEMBAHASAN} Keragaan Usahatani Sayuran

Hasil wawancara terhadap karakteristik usahatani sayuran menunjukkan bahwa sebanyak $64,71 \%$ petani sayuran menerapkan budidaya sayuran dengan pola tumpangsari dan sisanya sebesar $35,29 \%$ membudidayakan sayuran dengan pola monokultur. Pemilihan pola tumpangsari diakui petani bertujuan untuk mendapatkan penghasilan tambahan dengan memaksimalkan fungsi lahan yang diusahakan. Sebanyak $70,59 \%$ petani mengusahakan sayuran sebagai usaha utama, sedangkan sisanya sebesar 29,41\% berstatus usaha sampingan. Hal ini dikarenakan bertani merupakan mata pencaharian utama di lokasi penelitian, ditambah kesesuaian lahan untuk ditanami berbagai jenis sayuran. Usahatani sayuran pada umumnya diusahakan diatas lahan non milik. Hal ini ditunjukkan oleh 55,87\% usahatani sayuran diusahakan diatas lahan sewa, gadai, bagi hasil, dan HGU (Hak Guna Usaha). Hanya 44,12\% usahatani sayuran yang diusahakan diatas lahan milik. Karakteristik usahatani sayuran lebih lengkap ditunjukkan Tabel 1. 
Tabel 1. Karakteristik Usahatani Sayuran di Desa Citapen, Kecamatan Ciawi Tahun 2012

\begin{tabular}{|c|c|c|c|c|c|}
\hline \multirow[b]{2}{*}{ No. } & \multirow[b]{2}{*}{ Karakteristik Responden } & \multicolumn{3}{|c|}{ Jumlah Petani (Orang) } & \multirow[b]{2}{*}{$\begin{array}{c}\text { Persentase } \\
\text { (\%) }\end{array}$} \\
\hline & & $\begin{array}{c}\text { Petani } \\
\text { mitra }\end{array}$ & $\begin{array}{c}\text { Petani non } \\
\text { mitra }\end{array}$ & Jumlah & \\
\hline \multirow[t]{3}{*}{1} & Pola Usahatani & & & & \\
\hline & a. Tumpangsari & 16 & 8 & 24 & 64,71 \\
\hline & b. Monokultur & 4 & 6 & 10 & 35,29 \\
\hline \multirow[t]{3}{*}{2} & Status Usaha & & & & \\
\hline & a. Utama & 13 & 11 & 24 & 70,59 \\
\hline & b. Sampingan & 7 & 3 & 10 & 29,41 \\
\hline \multirow[t]{3}{*}{3} & Status Kepemilikan Lahan & & & & \\
\hline & a. Lahan Milik Sendiri & 11 & 4 & 15 & 44,12 \\
\hline & b. Lahan Non Milik & 9 & 10 & 12 & 55,87 \\
\hline \multirow[t]{4}{*}{4} & Umur Petani (tahun) & & & & \\
\hline & a. $20-40$ & 4 & 6 & 1 & 29,41 \\
\hline & b. $\quad 41-60$ & 10 & 5 & 15 & 44,12 \\
\hline & c. $\geq 61$ & 6 & 3 & 9 & 26,47 \\
\hline \multirow[t]{3}{*}{5} & Tingkat Pendidikan & & & & \\
\hline & a. $\mathrm{SD} /$ sederajat & 17 & 10 & 27 & 79,42 \\
\hline & b. Diatas SD/sederajat & 3 & 4 & 7 & 20,58 \\
\hline \multirow[t]{4}{*}{6} & Luas Lahan (Hektar) & & & & \\
\hline & a. $\leq 0,5$ & 11 & 2 & 13 & 38,24 \\
\hline & b. $0,5-2$ & 8 & 10 & 18 & 52,94 \\
\hline & c. $\geq 2$ & 0 & 2 & 2 & 5,88 \\
\hline \multirow[t]{4}{*}{7} & $\begin{array}{l}\text { Pengalaman bertani sayuran } \\
\text { (tahun) }\end{array}$ & & & & \\
\hline & a. $1-10$ & 8 & 5 & 13 & 38,24 \\
\hline & b. $10,1-20$ & 4 & 4 & 8 & 23,52 \\
\hline & c. $\geq 20,1$ & 8 & 5 & 13 & 38,24 \\
\hline
\end{tabular}

Rata-rata umur petani berkisar pada usia 41-60 tahun, artinya petani yang menjalankan usahatani digolongkan usia produktif. Petani pada usia ini mendominasi dengan persentase sebesar $44,12 \%$. Petani yang lebih muda yaitu usia 20-40 tahun sebesar 29,41\%, sedangkan petani yang berusia lanjut yaitu diatas 60 tahun masih cukup banyak dengan persentase $26,47 \%$. Petani dengan usia dibawah atau diatas rata-rata dan usia diatas 41-60 tahun diduga mempunyai kemampuan mengelola usahatani sayuran lebih rendah. Petani yang lebih muda umumnya belum memiliki banyak pengalaman dalam berusahatani, sedangkan petani yang berusia lanjut kemampuan, tenaga, dan daya juang dalam usahatani sudah mulai melemah.

Pendidikan formal petani masih didominasi oleh tamatan $\mathrm{SD} /$ sederajat sebesar 79,42\%. Adapun petani yang menempuh pendidikan diatas SD hanya 20,58\%. Pendidikan dianggap berpengaruh positif pada kemampuan mengelola usahatani sayuran. Pendidikan petani yang rendah diduga menyebabkan kegiatan usahatani menjadi kurang efisien. 
Rata-rata luas lahan yang dikelola petani antara 0,5-2 hektar baik berupa lahan milik maupun non milik. Luas lahan ini tidak semuanya ditanami sayuran. Luas lahan yang dikelola petani mitra umumnya masih sempit dengan luasan lahan kurang dari 0,5 hektar. Petani dengan luas lahan diatas 2 hektar hanya $5,88 \%$ dan merupakan petani non mitra, artinya tidak ada petani mitra yang mengelola lahan diatas 2 hektar. Kondisi ini menunjukkan umumnya petani mitra atau petani yang bergabung dengan Gapoktan adalah petani kecil.

Petani umumnya sudah memiliki cukup pengalaman dalam menjalankan usahatani sayuran. Rata-rata petani sudah menjalankan kegiatan usahatani sayuran diatas 10 tahun. Hal tersebut disebabkan bertani sayuran sudah dilakukan secara turun temurun. Kondisi tersebut juga didukung oleh kesesuaian lahan di lokasi penelitian untuk bertani sayuran.

Petani memilih bertani sayuran karena beberapa alasan. Alasan paling utama adalah kecocokan atau kesesuaian lahan untuk ditanami sayuran. Alasan kedua karena sayuran lebih cepat panen dibandingkan tanaman pangan atau palawija. Umumnya petani terutama petani yang sifat usahataninya merupakan usaha utama, lebih banyak menanam jenis sayuran yang berumur pendek agar cepat panen sehingga cepat memegang uang. Petani yang memiliki pekerjaan utama diluar usahatani sayuran memiliki alasan berbeda seperti menambah penghasilan atau alasan lain yang ditunjukkan oleh Tabel 2.

\section{Penggunaan Input Produksi}

Dalam kegiatan usahatani, faktor penting yang harus tersedia adalah input produksi. Input produksi pada usahatani sayuran terdiri dari lahan, pupuk, benih, tenaga kerja, dan obat-obatan. Rata-rata penggunaan input produksi per hektar selama satu tahun yaitu tahun 2012 oleh petani sayuran baik petani mitra maupun petani non mitra dapat dilihat pada Tabel 3. Rata-rata penggunaan input produksi petani anggota Gapoktan atau petani mitra per hektar lebih tinggi dibandingkan petani bukan anggota Gapoktan atau petani non mitra. Penggunaan input ini tidak terlepas dari peran Gapoktan dalam membantu menyediakan sarana prasarana produksi pertanian maupun pinjaman modal berupa uang tunai kepada petani mitra.

Pinjaman Gapoktan berasal dari dana PUAP (Program Usahatani Agribisnis Perdesaan) yang diberikan kepada Gapoktan dari pemerintah untuk digunakan sebagai dana pinjaman bagi petani anggota melalui Lembaga Keuangan Mikro Agribinis (LKMA). Pinjaman modal dapat diterima petani anggota Gapoktan dalam bentuk uang tunai maupun paket natura saprodi yang disesuaikan dengan jenis komoditi dan mengacu pada kontrak kesepatan anggota Gapoktan. Pinjaman ini dikembalikan petani mitra secara berkala melalui pemotongan pembayaran hasil panen sayuran ketika dijual ke Gapoktan. Penggunaan input yang lebih banyak juga dikarenakan sebagian besar petani mitra menerapkan pola tumpangsari sehingga input produksi yang dibutuhkan lebih banyak. 
Tabel 2. Alasan Bertani Sayuran Petani di Desa Citapen, Kecamatan Ciawi Tahun 2012

\begin{tabular}{|c|c|c|c|c|c|}
\hline \multirow[b]{2}{*}{ No. } & \multirow[b]{2}{*}{ Alasan Bertani Sayuran } & \multicolumn{3}{|c|}{ Jumlah Petani (Orang) } & \multirow[b]{2}{*}{$\begin{array}{c}\text { Persentase } \\
(\%)\end{array}$} \\
\hline & & $\begin{array}{l}\text { Petani } \\
\text { Mitra }\end{array}$ & $\begin{array}{c}\text { Petani } \\
\text { Non Mitra }\end{array}$ & Jumlah & \\
\hline 1. & Tradisi/turun temurun & 3 & 0 & 3 & 8,82 \\
\hline 2. & Hobi/kesenangan/keterampilan & 2 & 2 & 4 & 11,76 \\
\hline 3. & Kecocokan lahan & 5 & 7 & 12 & 35,29 \\
\hline 4. & Modal yang terbatas & 0 & 1 & 1 & 2,94 \\
\hline 5. & Cepat panen & 5 & 3 & 8 & 23,53 \\
\hline 6. & $\begin{array}{l}\text { Menambah penghasilan/pekerjaan } \\
\text { sampingan }\end{array}$ & 3 & 1 & 4 & 11,76 \\
\hline 7. & Budidaya yang mudah & 1 & 0 & 1 & 2,94 \\
\hline 8. & Daripada tidak kerja & 1 & 0 & 1 & 2,94 \\
\hline
\end{tabular}

Petani mitra lebih banyak menggunakan pupuk kandang sedangkan petani non mitra lebih banyak menggunakan pupuk kimia. Pupuk kandang lebih banyak digunakan petani mitra karena harganya lebih murah dibandingkan pupuk kimia. Satu karung pupuk kandang kambing setara 40-50 $\mathrm{Kg}$ harganya hanya Rp 5.000-Rp 6.000 dan pupuk kandang ayam seharga Rp 9.000Rp 10.000 per karung. Sementara pupuk kimia, seperti urea yang merupakan pupuk kimia paling terjangkau harganya mencapai Rp 90.000 per bal atau setara 50 Kg. Di samping itu, pupuk kandang mudah didapat petani mitra karena Gapoktan memiliki unit usaha peternakan domba dan ayam.

Petani non mitra mampu mengakses pupuk kimia lebih banyak disebabkan rata-rata petani non mitra adalah petani menengah dengan luasan lahan usahatani umumnya lebih luas daripada petani mitra. Di samping itu, petani non mitra juga memiliki rata-rata modal usahatani berupa uang tunai yang disiapkan untuk kegiatan usahatani lebih besar.
Jenis sayuran yang dipilih petani pada umumnya didasarkan pada kondisi cuaca dan kesesuaian lahan. Dalam waktu satu tahun pada tahun 2012, sayuran yang paling banyak dibudidayakan oleh petani adalah cabai, buncis, caisin, dan kacang panjang. Sayuran ini pada umumnya sayuran berumur pendek yang memiliki umur panen relative cepat.

Petani mitra lebih banyak menggunakan tenaga kerja luar keluarga (TKLK) dibandingkan tenaga kerja dalam keluarga (TKDK). Sedangkan petani non mitra menggunakan TKLK dan TDLK dengan komposisi hampir seimbang. Kondisi ini terjadi karena ratarata petani mitra memiliki lahan budidaya jauh dari tempat tinggal, sehingga membutuhkan waktu yang lebih lama dalam penyelesaian kegiatan budidaya. Oleh karena itu membutuhkan banyak bantuan tenaga kerja luar keluarga untuk mempercepat tahapan kegiatan budidaya. Di samping itu, 30\% petani mitra berusia diatas 60 tahun yang menyebabkan tahapan budidaya membutuhkan banyak tenaga tambahan dari luar keluarga. Kondisi ini juga didukung oleh fasilitas 
Gapoktan berupa penyediaan tenaga kerja dadakan bagi petani anggota yang membutuhkan dengan pembayaran upah ditunda hingga panen melalui pemotongan pembayaran hasil panen.

Luas sempitnya lahan budidaya akan berpengaruh terhadap hasil produksi sayuran. Luasan lahan yang diusahakan petani sayuran di Desa Citapen pada tahun 2012 ditunjukkan oleh Tabel 4. Secara umum lahan yang diusahakan petani mitra untuk budidaya sayuran selama satu tahun 2012 lebih kecil dibandingkan petani non mitra. Petani mitra membudidayakan sayuran dengan luas tanam rata-rata 1,12 hektar selama satu tahun 2012 yang terdiri dari 3-4 musim tanam. Sementara petani non mitra mencapai rata-rata luas tanam 1,40 hektar selama satu tahun untuk 3-4 musim tanam. Petani non mitra umumnya mengusahakan sayuran diatas lahan non milik yang luasnya dipengaruhi oleh seberapa mampu petani menyewa atau menggadai lahan tertentu. Sementara petani mitra lebih banyak mengusahakan sayuran diatas lahan milik yang rata-rata luasnya dibawah 0,5 hektar.

Tabel 3. Rata-Rata Penggunaan Input Produksi per Hektar di Desa Citapen Kecamatan Ciawi Tahun 2012

\begin{tabular}{|c|c|c|c|c|}
\hline No. & Input Produksi & Satuan & Petani mitra & $\begin{array}{c}\text { Petani non } \\
\text { mitra }\end{array}$ \\
\hline 1. & Lahan & Hektar & 1 & 1 \\
\hline 2. & Pupuk Kandang & $\mathrm{Kg}$ & $9.183,2$ & 5050 \\
\hline \multirow[t]{6}{*}{3.} & Pupuk Kimia: & & & \\
\hline & Pupuk Urea & $\mathrm{Kg}$ & 284,92 & 271,65 \\
\hline & Pupuk TSP & $\mathrm{Kg}$ & 69,45 & 152,55 \\
\hline & Pupuk KCL & $\mathrm{Kg}$ & 119,55 & 114,11 \\
\hline & Pupuk NPK & $\mathrm{Kg}$ & 133,93 & 113,85 \\
\hline & Pupuk Lainnya & $\mathrm{Kg}$ & 144,57 & 97,53 \\
\hline \multicolumn{2}{|c|}{ Total Pupuk Kimia } & $\mathrm{Kg}$ & 752,42 & 749,69 \\
\hline \multirow[t]{11}{*}{4.} & Benih Sayuran: & & & \\
\hline & Benih Cabai & Gram & 124,2 & 101,9 \\
\hline & Benih Buncis & $\mathrm{Kg}$ & 12,81 & 15,39 \\
\hline & Benih Caisin & Ons & 11,09 & 2,25 \\
\hline & Benih Kacang Panjang & $\mathrm{Kg}$ & 14,77 & 6,83 \\
\hline & Benih Kapri & $\mathrm{Kg}$ & 0,63 & 0,06 \\
\hline & Benih Terung & Gram & 101,7 & 43,8 \\
\hline & Benih Tomat & Gram & 57,4 & 99,7 \\
\hline & Benih Jagung Sayur & $\mathrm{Kg}$ & 1,50 & 0,98 \\
\hline & Benih Kacang Edamame & $\mathrm{Kg}$ & 0,00 & 2,86 \\
\hline & Benih Timun & Gram & 69,3 & 77,9 \\
\hline \multirow[t]{3}{*}{5.} & Tenaga Kerja: & & & \\
\hline & Tenaga Kerja Dalam Keluarga & $\mathrm{HOK}$ & 45,09 & 41,34 \\
\hline & Tenaga Kerja Luar Keluarga & $\mathrm{HOK}$ & 55,36 & 48,51 \\
\hline \multirow[t]{3}{*}{6.} & Obat-obatan: & & & \\
\hline & Obat-obatan Padat & $\mathrm{Kg}$ & 13,01 & 18,97 \\
\hline & Obat-obatan Cair & Liter & 14,29 & 9,75 \\
\hline
\end{tabular}


Tabel 4. Rata-Rata Penggunaan Lahan per Tahun di Desa Citapen Tahun 2012

\begin{tabular}{lcc}
\hline \multirow{2}{*}{ Luas Lahan } & \multicolumn{2}{c}{ Petani } \\
\cline { 2 - 3 } & Petani mitra & Petani non mitra \\
\hline Rata-rata Luas Lahan yang Dimiliki (Ha) & 0,56 & 1,43 \\
\hline $\begin{array}{l}\text { Rata-rata Luas lahan yang dialokasikan untuk } \\
\text { budidaya sayuran (Ha) }\end{array}$ & 0,475 & 0,93 \\
\hline $\begin{array}{l}\text { Rata-rata Luas Pengusahaan Lahan Budidaya } \\
\text { Sayuran per Tahun (Ha/tahun) }\end{array}$ & 1,12 & 1,40 \\
\hline
\end{tabular}

Bagi petani mitra yang umumnya adalah petani gurem, adanya fasilitas penyediaan sarana prasarana produksi (saprodi) berupa input-input produksi usahatani sangat membantu petani menjamin keberlangsungan kegiatan usahatani. Hal ini dikarenakan petani gurem umumnya memiliki keterbatasan modal untuk mengakses saprodi. Pendapat ini didukung oleh peneliti Key N dan David (1999) yang menyatakan bahwa salah satu manfaat petani mengikuti pertanian kontrak adalah tersedianya fasilitas penyediaan saprodi yang dapat diakses oleh petani. Fasilitas tersebut membantu petani dalam mempermudah mengadakan input-input produksi.

\section{Biaya Usahatani}

Biaya usahatani adalah keseluruhan biaya yang dikeluarkan petani selama kegiatan usahatani baik yang berkaitan langsung maupun tidak langsung dengan kegiatan produksi. Biaya ini meliputi biaya pengolahan lahan, biaya pengadaan benih, biaya pupuk dan obat-obatan, biaya tenaga kerja, biaya pemanenan, biaya penyusutan peralatan, dan biaya pasca panen yang meliputi biaya pengangkutan, biaya sortir atau grading, pajak pasar, retribusi, dan biaya lain-lain.

Total biaya yang dikeluarkan petani mitra sebesar Rp 15.543.070 yang terdiri dari $93,64 \%$ total biaya tunai dan $6,36 \%$ total biaya diperhitungkan. Sedangkan total biaya yang dikeluarkan petani non mitra sebesar Rp 14.384.189 yang terdiri dari 90,72\% total biaya tunai dan 9,28\% total biaya diperhitungkan. Komponen biaya terbesar yang harus dikeluarkan petani baik petani mitra maupun petani non mitra sama yaitu biaya benih yang mencapai $44,19 \%$ bagi petani mitra dan $38,93 \%$ bagi petani non mitra. Kemudian secara berturut-turut diikuti oleh biaya sewa lahan, dan biaya pupuk kimia. Sedangkan komponen biaya terkecil adalah biaya pupuk kandang dan tenaga kerja luar keluarga. Kondisi ini menguatkan alasan petani menggunakan banyak pupuk kandang dan tenaga kerja luar keluarga. Faktor penyebabnya yaitu harga pupuk kandang dan upah tenaga kerja luar keluarga yang tergolong murah.

Biaya diperhitungkan yang ditanggung oleh petani non mitra lebih besar dibandingkan petani mitra. Selisih biaya terlihat jelas pada biaya pasca panen. Hal ini disebabkan petani non mitra masih harus menanggung sendiri biaya pasca panen termasuk biaya pengangkutan hasil panen, biaya sortir/grading, dan biaya pemasaran. Sementara petani mitra dimudahkan dengan adanya alat pengangkutan hasil panen yang telah disiapkan Gapoktan untuk membawa hasil 
panen langsung ke Gapoktan tanpa dibebankan biaya ke petani. Adapun beban-beban biaya lain setelah itu, sepenuhnya menjadi tanggungan Gapoktan baik sorting/grading maupun pemasaran sayuran ke pasar induk. Kondisi ini juga menunjukkan manfaat kemitraan dalam menekan biaya pasca panen yang seharusnya ditanggung oleh petani, se-hingga total biaya usahatani dapat ditekan. Struktur biaya usahatani sayuran secara lebih lengkap disajikan pada Tabel 5.

\section{Analisis Pendapatan Usahatani}

Dalam usahatani, analisis pendapatan menggambarkan secara sederhana bagaimana tingkat kelayakan usahatani. Hasil analisis pendapatan usahatani sayuran dilokasi penelitian disajikan pada Tabel 6. Berdasarkan hasil analisis diketahui bahwa rata-rata produksi sayuran per hektar selama satu tahun petani mitra sebesar 47.761,39 kilogram sedangkan petani non mitra sebesar 49.875,87 kilogram. Dari hasil ini diketahui bahwa rata-rata produksi petani non mitra lebih tinggi dibandingkan petani mitra. Kondisi ini juga menunjukkan kemitraan belum mampu meningkatkan hasil produksi usahatani sayuran.

Secara finansial, rata-rata harga jual sayuran petani mitra sebesar Rp 3.239 per kilogram, sementara petani non mitra sebesar Rp 3.166 per kilogram. Perolehan harga yang lebih baik menunjukkan kemitraan mampu meningkatkan posisi tawar petani. Harga yang lebih tinggi yang diterima petani mitra seharusnya menyebabkan pendapatan usahatani semakin meningkat. Namun, karena hasil produksi yang lebih rendah dibandingkan petani non mitra, peningkatan pendapatan usahatani petani mitra belum terlihat secara signifikan. Hal ini dikarenakan pendapatan usahatani diukur oleh seberapa besar harga yang diperoleh dikalikan dengan jumlah produksi dan dikurangi dengan total biaya produksi. Sedangkan selisih harga yang diterima petani mitra dan non mitra relatif kecil. Oleh karena itu, dengan kemampuan menghasilkan jumlah produksi yang lebih besar, memungkinkan bagi petani non mitra untuk memperoleh pendapatan usahatani yang lebih besar.

Dari hasil analisis pendapatan ini menunjukkan bahwa manfaat kemitraan petani sayuran dengan Gapoktan Rukun Tani lebih kepada perolehan harga atau pemasaran hasil panen yang lebih baik namun belum terlihat pengaruh yang signifikan antara kegiatan kemitraan dengan peningkatan produksi sayuran petani mitra.

Hasil ini serupa dengan hasil penelitian Fischer dan Matin (2012) yang menemukan bahwa keanggotaan kelompok mengarah pada peningkatan pendapatan rumah tangga, namun hanya untuk petani yang juga memasarkan secara kolektif. Hal ini menggarisbawahi bahwa bukan keanggotaan kelompok yang penting, tetapi partisipasi anggota dalam kelompok. Begitu hal-nya dengan Gapoktan Rukun Tani yang menjamin perolehan harga dan pasar bagi sayuran petani mitra. 
Tabel 5. Struktur Biaya Usahatani per Hektar di Desa Citapen Kecamatan Ciawi Tahun 2012

\begin{tabular}{|c|c|c|c|c|c|}
\hline \multirow[b]{2}{*}{ No. } & \multirow[b]{2}{*}{ Rincian Biaya } & \multicolumn{4}{|c|}{ Rata-Rata Nilai (Rupiah) } \\
\hline & & $\begin{array}{c}\text { Petani } \\
\text { mitra }\end{array}$ & $\begin{array}{c}\text { Persentase } \\
(\%)\end{array}$ & $\begin{array}{c}\text { Petani non } \\
\text { mitra }\end{array}$ & $\begin{array}{c}\text { Persentase } \\
(\%)\end{array}$ \\
\hline \multicolumn{6}{|c|}{ Biaya Tunai: } \\
\hline 1. & Biaya Sewa Lahan & 2.134 .122 & 13,73 & 2.526 .977 & 17,57 \\
\hline \multirow[t]{3}{*}{2.} & Biaya Pupuk: & & & & \\
\hline & Biaya Pupuk Kandang & 1.388 .462 & 8,93 & 702.508 & 4,88 \\
\hline & Biaya Pupuk Kimia & 1.748 .446 & 11,25 & 1.658 .543 & 11,53 \\
\hline 3. & Biaya Benih & 6.869 .076 & 44,19 & 5.600 .432 & 38,93 \\
\hline 4. & Biaya Tenaga Kerja Luar Keluarga & 1.071 .175 & 6,89 & 957.488 & 6,66 \\
\hline & Biaya Obat-obatan & 1.343 .358 & 8,64 & 1.602 .984 & 11,14 \\
\hline \multicolumn{2}{|c|}{ Total Biaya Tunai } & 14.554.639 & 93,64 & 13.048.932 & 90,72 \\
\hline \multicolumn{6}{|c|}{ Biaya Diperhitungkan: } \\
\hline 1. & Biaya Tenaga Kerja Dalam Keluarga & 824.331 & & 844.328 & \\
\hline & Biaya Pasca Panen & 48.100 & & 356.928 & \\
\hline & Biaya Penyusutan Peralatan & 116.000 & & 134.000 & \\
\hline \multicolumn{2}{|c|}{ Total Biaya Diperhitungkan } & 988.431 & 6,36 & 1.335.257 & 9,28 \\
\hline \multicolumn{2}{|c|}{ Total Biaya } & 15.543.070 & 100 & 14.384.189 & 100 \\
\hline
\end{tabular}

Tabel 6. Analisis Pendapatan Usahatani Sayuran per Hektar di Desa Citapen Tahun 2012

\begin{tabular}{lrr}
\hline \multicolumn{1}{c}{ Komponen } & Petani mitra & Petani non mitra \\
\hline Rata-Rata Harga $(\mathrm{Rp} / \mathrm{Kg})$ & 3.239 & 3.166 \\
Total Produksi Per Tahun $(\mathrm{Kg})$ & $47.761,39$ & $49.875,87$ \\
Total Penerimaan (a) (Rp) & 154.699 .148 & 157.907 .025 \\
Biaya Tunai (b) (Rp) & 14.554 .639 & 13.048 .932 \\
Biaya Diperhitungkan (c) (Rp) & 988.431 & 1.335 .257 \\
Biaya Total Usahatani (d = b + c ) (Rp) & 15.543 .070 & 14.384 .189 \\
\hline Pendapatan Usahatani atas Biaya Tunai (a - b) (Rp) & 140.144 .51 & 144.858 .093 \\
Pendapatan Usahatani atas Biaya Total (a-d) (Rp) & 139.156 .08 & 143.522 .841 \\
\hline R/C atas biaya tunai & 10,63 & 12,10 \\
R/C atas biaya total & 9,95 & 10,98 \\
\hline
\end{tabular}

Gapoktan mampu membeli sayuran petani mitra dengan harga rata-rata lebih tinggi dari harga umum disebabkan Gapoktan mampu memasarkan sayuran petani mitra secara kolektif langsung ke pasar induk TU Kemang Bogor, sehingga harga yang diterima relatif lebih tinggi dari harga di tingkat pedagang pengumpul. Oleh karena itu, petani mitra mengakui pendapatan usahataninya masih lebih baik dibandingkan sebelum bergabung dengan Gapoktan atau menjalankan usahatani secara individu.

Dari 20 petani mitra yang menjadi responden, diketahui hanya sekitar 9 responden yang diakui oleh Gapoktan sebagai anggota aktif, sisanya adalah anggota pasif yang datang ke Gapoktan hanya Artinya, kegiatan-kegiatan Gapoktan seperti sekolah lapang, penyuluhan, dan bimbingan teknis kurang dimanfaatkan oleh anggota. Partisipasi anggota yang rendah juga diakui oleh pengurus 
Gapoktan sebagai akibat minimnya pengetahuan anggota akan manfaat dari kegiatan tersebut serta alasan petani merasa rugi jika harus meninggalkan pekerjaan untuk mengikuti kegiatankegiatan yang diselenggarakan Gapoktan.

Bellemare (2012) mendukung temuan ini dengan menunjukkan bahwa kenaikan 1 persen partisipasi petani dalam pertanian kontrak dikaitkan dengan peningkatan 0,5 persen dalam pendapatan rumah tangga. Hasil empiris menunjukkan bahwa peningkatan 1 persen partisipasi petani dalam pertanian kontrak dikaitkan dengan rata-rata kenaikan 0,5 persen dalam pendapatan rumah tangga per setara dewasa, dan kenaikan 0,5 persen dalam pendapatan rumah tangga. Dari hasil penelitian Bellemare (2012) ini dapat disimpulkan bahwa kenaikan partisipasi anggota harus lebih besar jika ingin melihat pengaruh pertanian kontrak terhadap peningkatan pendapatan.

Berdasarkan informasi yang diperoleh dari pengurus Gapoktan, diketahui faktor-faktor yang menyebabkan hasil produksi petani anggota Gapoktan lebih rendah dibandingkan petani bukan anggota Gapoktan. Faktorfaktor tersebut antara lain: (1) penggunaan input-input produksi yang berlebihan oleh petani anggota Gapoktan. Petani mitra pada umumnya mengambil input produksi lebih banyak dari jumlah yang dianjurkan oleh pengurus Gapoktan.

Faktor yang kedua (2) yaitu untuk musim tanam tahun 2012 banyak sayuran petani mitra yang terserang hama dan penyakit. Hal ini diakui oleh pengurus Gapoktan dengan seringnya pihak
Gapoktan menerima keluhan tentang serangan hama dan penyakit yang menyerang tanaman budidaya petani mitra. Kemampuan manajerial yang rendah serta pengetahuan terhadap penanggulangan hama dan penyakit yang kurang baik, menyebabkan petani mitra sering mengalami hambatan dalam penanganan hama dan penyakit.

Pengelolaan budidaya yang kurang baik oleh petani mitra juga disebabkan oleh kurangnya partisipasi petani mitra dalam mengikuti kegiatan bimbingan, pelatihan, dan penyuluhan baik oleh pihak Gapoktan maupun penyuluh yang bertugas. Penyuluhan maupun pelatihanpelatihan seperti sekolah lapang dan kegiatan kunjungan umumnya hanya diikuti pengurus inti masing-masing kelompok tani seperti ketua dan sekretaris setiap kelompok tani. Diharapkan dari kegiatan tersebut, ketua dan sekretaris setiap kelompok tani dapat meneruskan materi penyuluhan ke anggota. Namun kenyataan di lapangan, banyak pengurus kelompok tani yang kurang aktif di samping terbatasnya anggaran kelompok tani untuk melakukan bimbingan masal kepada anggota.

Nilai $\mathrm{R} / \mathrm{C}$ rasio masing-masing petani responden baik petani mitra maupun petani non mitra sudah lebih dari 1. Hal ini menunjukkan kegiatan usahatani sayuran yang dijalankan petani sudah menguntungkan. Namun seperti halnya penerimaan dan pendapatan usahatani, nilai $\mathrm{R} / \mathrm{C}$ rasio petani mitra lebih kecil dibandingkan petani non mitra. Nilai R/C rasio atas biaya tunai untuk usahatani yang dijalankan petani mitra sebesar 10,63 lebih kecil jika dibandingkan 
dengan petani non mitra yang memperoleh nilai $\mathrm{R} / \mathrm{C}$ rasio sebesar 12,10 . Hal ini menunjukkan bahwa kegiatan usahatani petani non mitra lebih efisien.

Kondisi tersebut diduga bahwa kegiatan usahatani yang dilakukan petani non mitra lebih efisien disebabkan penggunaan input-input produksi yang lebih efisien, sehingga produksi menjadi lebih baik dibandingkan petani mitra. Dengan jumlah produksi yang lebih baik, penerimaan yang diperoleh petani non mitra semakin besar. Sedangkan biaya total yang dikeluarkan petani non mitra mampu ditekan akibat penggunaan inputinput produksi yang lebih efisien atau lebih hemat dibandingkan petani mitra. Oleh karena itu, rasio antara penerimaan dengan biaya total yang dikeluarkan lebih besar dibandingkan petani mitra.

Demikian pula untuk nilai $\mathrm{R} / \mathrm{C}$ atas biaya total. Petani mitra memperoleh nilai $\mathrm{R} / \mathrm{C}$ atas biaya total lebih kecil yaitu sebesar 9,95 dibandingkan petani non mitra yang memperoleh nilai $\mathrm{R} / \mathrm{C}$ atas biaya total sebesar 10,98. Nilai R/C yang lebih kecil menunjukkan jumlah biaya yang ditanggung petani mitra lebih besar yang mengakibatkan berkurangnya jumlah pendapatan usahatani. Biaya usahatani yang besar diduga disebabkan oleh penggunaan input-input produksi yang berlebihan dan justru berpengaruh negatif terhadap hasil produksi. Biaya pengadaan input yang besar tidak diimbangi dengan peningkatan produksi menyebabkan pendapatan usahatani rendah. Hal ini dapat dijelaskan bahwa kegiatan usahatani yang dilakukan petani mitra sudah berada pada kondisi Decreasing Return To Scale (DRTS) yaitu kondisi dimana setiap tambahan input produksi justru akan mengurangi tambahan output produksi.

\section{Faktor-Faktor yang Berpengaruh terhadap Minat Petani Mengikuti Kemitraan}

Penilaian petani responden terhadap kinerja Gapoktan perlu diketahui karena berpengaruh terhadap minat responden untuk melakukan kemitraan atau tidak dengan Gapoktan. Kinerja Gapoktan tercermin dari fasilitas yang diberikan serta pelayanan terhadap petani anggota. Kelembagaan Gapoktan dinilai penting keberadaannya apabila mampu memberikan manfaat bagi para anggotanya melalui pemberian faslitas serta sarana prasaran yang dibutuhkan petani dalam rangka mendukung dan memperlancar usahataninya.

Fasilitas Gapoktan yang paling dirasakan manfaatnya oleh petani anggota di lokasi penelitian secara berturut-turut adalah informasi harga sayuran di tingkat petani yang transaparan dan jelas, syarat masuk awal menjadi anggota yang mudah, dan kemudahan memperoleh input produksi dari Gapoktan, yang diakui oleh 85\% petani mitra, pembayaran hasil panen sayuran lancar dan adanya bantuan pinjaman modal berupa uang atau paket natura saprodi untuk usahatani sayuran yang diakui oleh $75 \%$ petani mitra, serta selalu tersedianya fasilitas pengangkutan hasil panen yang diakui oleh $70 \%$ petani mitra. Sementara fasilitas yang masih kurang dirasakan manfaatnya oleh petani anggota adalah harga input produksi yang masih sama dengan harga pasar, serta 
kegiatan bimbingan, pelatihan, dan penyuluhan yang intensitasnya masih jarang dilakukan oleh Gapoktan.

Sebagian besar responden (85\%) mengungkapkan bahwa pelayanan Gapoktan sudah cukup baik. Hal ini terlihat dari beberapa layanan yang dirasakan oleh petani mitra yaitu tujuan dibentuknya Gapoktan untuk meningkatkan kesejahteraan anggota, pengurus memberikan pelayanan dengan baik sesuai dengan hak dan kewajiban anggota, Gapoktan menyediakan fasilitas dan sarana prasarana pertanian yang dibutuhkan petani, serta Gapoktan mampu meningkatkan posisi tawar dan pendapatan petani dibandingkan sebelum bermitra dengan Gapoktan.

Sementara itu faktor-faktor yang mendasari petani non mitra tidak berminat melakukan kemitraan dengan Gapoktan antara lain: (1) lokasi lahan dan tempat tinggal yang jauh dari Gapoktan, (2) terdapat pedagang pengumpul disekitar lokasi lahan, sehingga lebih cepat menjual sayuran ke pengumpul, (3) rata-rata petani non mitra memiliki modal dan skala usahatani cukup besar, sehingga tidak memerlukan fasilitas Gapoktan, (4) beberapa petani juga bertindak sebagai pedagang atau pemasok sayuran sehingga tidak bersedia menjual sayuran ke Gapoktan, atau mampu secara individu melakukan penjualan langsung ke pasar induk, dan (5) responden tidak menyukai kegiatan administratif yang rumit, serta adanya anggapan bahwa kegiatan Gapoktan hanya menguntungkan beberapa pihak saja (adanya konflik dengan beberapa pengurus inti Gapoktan).
Fakta lain yang mendasari petani non mitra mampu melakukan usahatani lebih baik karena pada umumnya petani non mitra adalah petani besar yang skala pengusahaan usahatani lebih luas sehingga lebih memperhitungkan dengan cermat dalam penggunaan input-input produksi per luasan lahan yang diusahakan untuk menghindari kerugian. Di samping itu, petani non mitra harus mengeluarkan biaya secara tunai karena tidak mendapat fasilitas dari Gapoktan, sehingga besar kecilnya jumlah input yang akan dibeli benar-benar diperhitungkan dan disesuaikan dengan besarnya uang tunai yang dipegang petani.

Sementara itu, petani mitra meskipun memiliki luasan lahan yang lebih sempit, dimudahkan dalam pengadaan input produksi karena mendapatkan fasilitas dari Gapoktan. Petani mitra dapat mengajukan pinjaman ke Gapoktan berupa paket natura saprodi atau modal usahatani dalam bentuk uang tunai. Untuk paket natura produksi, pada umumnya petani mengambil input produksi lebih banyak daripada anjuran yang telah disampaikan oleh Gapoktan. Hal ini menguatkan pendapat bahwa dalam kegiatan usahataninya petani mitra menggunakan input produksi yang kurang efisien, sehingga justru berpengaruh negatif terhadap hasil produksi dan mengurangi pendapatan usahatani.

Secara umum kemitraan yang dijalankan oleh Gapoktan Rukun Tani dengan petani sayuran memberikan cukup banyak manfaat terutama dilihat dari berbagai fasilitas yang diberikan dan dapat diakses oleh petani anggota. 
Fasilitas tersebut meliputi penyediaan input-input produksi, pinjaman modal berupa uang tunai maupun paket natura saprodi, penyediaan kendaraan pengangkut hasil panen, dan jaminan pasar bagi sayuran petani. Harga yang diberikan Gapoktan juga relatif lebih tinggi dari rata-rata harga di tingkat pedagang pengumpul karena pemasaran kolektif memungkinkan penekanan pada biaya transaksi serta mampu menembus pasar yang lebih besar. Hal ini dapat dijelaskan bahwa manfaat kemitraan lebih kepada pelayanan untuk memperlancar kegiatan usahatani dan fasilitas pasca panen. Akan tetapi, pelayanan dalam kegiatan budidaya secara langsung dalam membantu petani anggota untuk berproduksi lebih baik belum terlihat dalam kemitraan.

Penelitian mengenai pengaruh pertanian kontrak atau kemitraan terhadap perbaikan kegiatan usahatani serta peningkatan pendapatan dengan hubungan positif telah banyak dilakukan oleh peneliti sebelumnya, diantaranya Key N dan David (1999); Barham dan Clarence (2009); Hellin et al. (2009); dan Tita et al. (2011). Hasil penelitian dari keempat peneliti ini memiliki kesamaan dengan kemitraan yang dijalankan oleh Gapoktan Rukun Tani terutama dalam hal peran kemitraan dalam meningkatkan akses petani ke pasar dengan meningkatkan posisi tawar mereka, daya saing hasil produksi, serta mengurangi biaya transaksi.

\section{KESIMPULAN}

Kegiatan usahatani sayuran di Desa Citapen Kecamatan Ciawi, Kabupaten Bogor baik oleh petani mitra maupun petani non mitra sudah menguntungkan. Namun, kemitraan yang dijalankan petani sayuran dengan Gapoktan belum mampu meningkatkan produksi dan pendapatan usahatani lebih baik dibandingkan petani non mitra. Peningkatan pendapatan yang dicapai oleh petani mitra masih lebih rendah dibandingkan pendapatan ratarata petani non mitra. Hal ini ditunjukkan oleh total hasil produksi rata-rata, pendapatan usahatani, serta nilai $\mathrm{R} / \mathrm{C}$ rasio petani mitra yang lebih kecil dibandingkan petani non mitra.

Faktor yang paling berpengaruh terhadap keputusan petani menjalin kemitraan dengan Gapoktan adalah syarat awal masuk menjadi anggota mudah, adanya bantuan pinjaman modal, informasi harga sayuran transparan dan jelas, kemudahan memperoleh input produksi, pembayaran hasil panen lancar, dan selalu tersedia fasilitas pengangkutan hasil panen. Adapun alasan petani yang memilih untuk tidak bermitra dengan Gapoktan meliputi lokasi lahan jauh dari Gapoktan, kepraktisan menjual hasil panen ke pengumpul, modal dan skala usahatani yang cukup besar, kepentingan menjual atau memasok sayuran, tidak menyukai kegiatan administratif yang dianggap rumit, serta ada anggapan bahwa kegiatan Gapoktan menguntungkan pihak tertentu saja (konflik dengan pengurus Gapoktan). 
Pengaruh kemitraan antara Gapoktan Rukun Tani dengan petani anggota lebih terlihat pada kemampuannya dalam menjamin pasar bagi sayuran hasil panen petani, insentif harga yang lebih tinggi, serta penekanan pada biaya pasca panen. Namun kemitraan belum mampu meningkatkan hasil produksi sehingga pengaruh pada peningkatan pendapatan belum terlihat secara signifikan.

\section{UCAPAN TERIMA KASIH}

Terima kasih kami ucapkan kepada Biro Perencanaan dan Kerjasama Luar Negeri (BPKLN) Kementerian Pendidikan dan Kebudayaan Republik Indonesia yang telah memberikan beasiswa selama masa studi di Program Studi Magister Sains Agribisnis, Institut Pertanian Bogor.

\section{DAFTAR PUSTAKA}

Barham J and Clarence Chitemi. 2009. Collective Action Initiatives to Improve Marketing Performance: Lessons From Farmer Groups in Tanzania. Journal of Food Policy, $34 \quad$ (53-59), 2009. www.elsevier.com/locate/foodpol. Diakses 26 Februari 2014.

Bellemare MF. 2012. As You Sow, So Shall You Reap: The Welfare Impacts of Contract Farming. Journal of World Development Vol. 40, No. 7, pp. 1418-1434, 2012.
Berkama A and M Drabenstott. 1995. The Many Paths of Vertical Coordination: Structural Implication for the US Food System. Agribusiness. Vol.11, No: 5, 483-492.

Bolwig S, Peter Gibbon, and Sam Jones. 2009. The Economics of Smallholder Organic Contract Farming in Tropical Africa. Journal of World Development, Vol. 37, No. 6, pp. 1094-1104, 2009.

[BPS] Badan Pusat Statistik. 2012. Perkembangan Produksi Sayuran Indonesia tahun 2002-2011.

Burch D and R E Rickson. 1990. Contract Farming and Rural Social Change: Some Implications of Australian Experience. Environmental Impact Assessment Review, 1990, 10:1/2 pp.145-155.

Fischer E and Matin Qaim. 2012. Linking Smallholders to Markets: Determinants and Impacts of Farmer Collective Action in Kenya. Journal of World Development, Vol. 40, No. 6, pp. 1255-1268, 2012.

Hafsah M. Jafar. 1999. Kemitraan Usaha: Konsepsi dan Strategi. Penerbit Pustaka. Sinar Harapan Jakarta. Jakarta.

Hellin J, Mark Lundy, Madelon Meijer. 2009. Farmer Organization, Collective Action and Market Access in Meso-America. Journal of Food Policy, 34(16-22), 2009. www.elsevier.com /locate/foodpol. Diakses tanggal 2 Maret 2014. 
Key N and David Runsten. 1999. Contract Farming, Smallholders, and Rural Development in Latin America: The Organization of Agroprocessing Firms and the Scale of Outgrower Production. Journal of World Development, Vol. 27, No. 2, pp. 381-401, 1999.

Masakure O and S Henson. 2005. Why

Do Small-Scale Producers Choose

To Produce Under Contracts? Lessons From Non-Traditional Vegetable Export From Zimbabwe. Journal of World Development, Vol. 33, Issues 10, pp. 1721-1733.

Rehber E. 1984. Norwegian Agriculture and Agricultural Marketing Through Cooperative Organizations. Ankara University Press No: 897. Ankara.

Rehber E. 1998. Vertical Integration in Agriculture and Contract Farming. Working Paper 46, May 1998. A Joint USDA Land Grant University Research Project, Food Marketing Policy Center, University of Connecticut, USA.

Sukhpalsingh. 2002. Contracting Out Solutions: Political Economy of Contract Farming in the Indian Punjab. Journal of World Development, Vol. 30, No. 9, pp. 1621-1638, 2002.
Tita DF, Marijke D'Haese, Ann Degrande, Zac Tchoundjeu, Patrick Van Damme. 2011. Farmers' Satisfaction With Group Market Arrangements As A Measure of Group Market Performance: A Transaction Cost Analysis of Non Timber Forest Products' Producer Groups In Cameroon. Journal of Forest Policy and Economics, 13(545-553), 2011. www.elsevier.com/locate/forpol. Diakses tanggal 3 Maret 2014. 